\title{
Application of a 980-nanometer diode laser in neuroendoscopy: a case series
}

\author{
Rodolfo Casimiro Reis, MD, ${ }^{1}$ Manoel Jacobsen Teixeira, PhD, ${ }^{2}$ Marilia Wellichan Mancini, PhD, ${ }^{3}$ \\ Luciana Almeida-Lopes, $\mathrm{PhD},{ }^{3}$ Matheus Fernandes de Oliveira, MD, ${ }^{1}$ and \\ Fernando Campos Gomes Pinto, $\mathrm{PhD}^{4}$
}

\begin{abstract}
${ }^{1}$ Neurosurgery Residency Program, Hospital do Servidor Público Estadual de São Paulo, São Paulo SP; 2 Division of Functional Neurosurgery of the Institute of Psychiatry, Hospital das Clínicas, Universidade de São Paulo; ${ }^{3}$ Núcleo de Pesquisa e Ensino de Fototerapia nas Ciências da Saúde - NUPEN, São Carlos SP; and ${ }^{4}$ Cerebral Hydrodynamics Department, Institute of Psychiatry, Hospital das Clínicas, Universidade de São Paulo, Brazil
\end{abstract}

OBJECTIVE Ventricular neuroendoscopy represents an important advance in the treatment of hydrocephalus. Highpower (surgical) Nd:YAG laser and low-level laser therapy (using 685-nm-wavelength diode laser) have been used in conjunction with neuroendoscopy with favorable results. This study evaluated the use of surgical 980 -nm-wavelength diode laser for the neuroendoscopic treatment of ventricular diseases.

METHODS Nine patients underwent a neuroendoscopic procedure with 980-nm diode laser. Complications and followup were recorded.

RESULTS Three in-hospital postoperative complications were recorded (1 intraventricular hemorrhage and 2 meningitis cases). The remaining 6 patients had symptom improvement after endoscopic surgery and were discharged from the hospital within 24-48 hours after surgery. Patients were followed for an average of 14 months: 1 patient developed meningitis and another died suddenly at home. The other patients did well and were asymptomatic until the last follow-up consultation.

CONCLUSIONS The 980-nm diode laser is considered an important therapeutic tool for endoscopic neurological surgeries. This study showed its application in different ventricular diseases.

http://thejns.org/doi/abs/10.3171/2014.12.JNS141561

KEY WORDS laser; neuroendoscopy; hydrocephalus; surgical technique

$\mathrm{V}$ ENTRICULAR neuroendoscopy represents an important advance in the treatment of hydrocephalus. About $30 \%$ of patients with hydrocephalus meet the criteria for this technique, which may prevent the need for a ventriculoperitoneal shunt, resulting in reduced costs and low incidence of late complications. . $, 5,6,7,12,15,17^{-17}$

Nonetheless, because a ventricular endoscope is used through a single bur hole, additional resources to enable cutting, coagulation, and ablation of injuries are extremely relevant to reduce surgical time and hospital length of stay, and increase the safety of the procedure and the patient's postoperative comfort. ${ }^{8,10,18}$ Increasing experience in several centers has proven that laser-assisted endoscopic pro- cedures are useful options, because they are safe, effective, and advantageous in cases of distorted anatomy. ${ }^{4,18}$

We have previously shown favorable results of surgical $\mathrm{Nd}: Y A G$ and therapeutic laser (diode $685 \mathrm{~nm}$ ) in neuroendoscopic procedures, such as excision of colloid cysts and myelomeningocele repair. ${ }^{10,11}$ Furthermore, the use of 980-nm diode laser in brain tissue of Wistar rats has been tested in recent studies and was associated with a remarkable ablating capacity, minimal thermal damage to surrounding tissue, and lower recovery time than other lasers with different wavelengths or electrocoagulators. ${ }^{1}$ The 980-nm-wavelength diode laser provides proper absorption in both water and hemoglobin, which is an ad-

ABBREVIATIONS $\mu_{A}\left(\mathrm{H}_{2} \mathrm{O}\right)=$ absorption coefficient of water; $\mathrm{CW}=$ continuous wave; $\mathrm{ETV}=$ endoscopic third ventriculostomy.

SUBMITTED July 10, 2014. ACCEPTED December 17, 2014.

INCLUDE WHEN CITING Published online July 10, 2015; DOI: 10.3171/2014.12.JNS141561.

DISCLOSURE The study was not sponsored by any organization. Laser equipment used was owned by Núcleo de Pesquisa e Ensino de Fototerapia nas Ciências da Saúde-NUPEN, São Carlos SP, Brazil, while the endoscope was owned by Hospital das Clínicas, Universidade de São Paulo SP, Brazil. 
vantage compared with Nd:YAG and lower-wavelength diode lasers. ${ }^{5}$

We propose the use of the 980-nm-wavelength diode laser for the neuroendoscopic treatment of ventricular diseases and describe its use in 9 cases. This technique will be described herein.

\section{Methods}

A consecutive series of 9 patients with congenital and acquired obstructive hydrocephalus was referred to Hospital das Clínicas, University of São Paulo, Brazil, from January 2012 to March 2013. All patients or their parents signed a consent form. This clinical study was approved by the Ethics Committee of our institution.

All surgeries were performed under general anesthesia. An 18-mm trephination was done and a rigid neuroendoscope with a $0^{\circ}$ or $30^{\circ}$ objective lens (Aesculap, 25-cm working length and 6-mm diameter) was introduced. An optical fiber coupled to a 980-nm diode laser (InGaAs/ GaAs) equipment (MediLaser $980 \mathrm{~nm}$; DMC Equipamentos LTDA) was used in all surgeries through the neuroendoscope's working channel (Fig. 1), with maximum continuous wave $(\mathrm{CW})$ output power of $25 \mathrm{~W}$, operating in $\mathrm{CW}$ mode, pulsed (modulated) mode with frequency operation interval ranging from 0.16 to $1.0 \mathrm{kHz}$ and pulse widths varying from $0.5 \mathrm{msec}$ to 6 seconds, as well as single-pulse mode. The laser was used with optical power ranging from 5 to $15 \mathrm{~W}$, except in 1 patient, in whom we used $20 \mathrm{~W}$ for the opening of the third ventricle floor. The laser was applied in CW and single-pulse mode operations set up with 1-second pulse width, for opening of the ventricle floor, delivered through biocompatible silica optical fibers with 400- and 600- $\mu \mathrm{m}$ core diameters (DMC Equipamentos LTDA) (Fig. 2) inserted through the neuroendoscope working channel. The laser energy was always applied in contact mode to avoid large optical penetration by direct radioactive transfer.

Postoperative complications were registered, and clinical and radiological follow-up was performed.

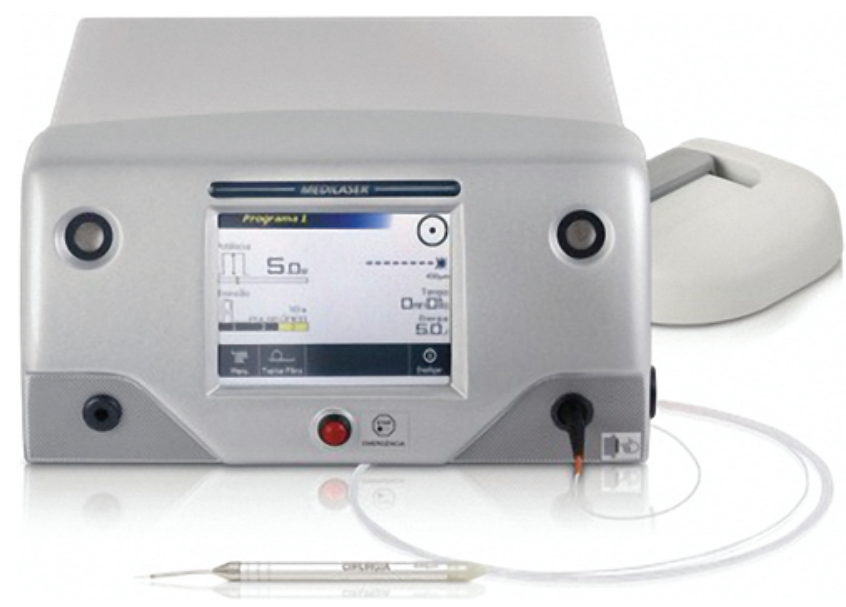

FIG. 1. Illustration showing the 980-nm diode laser equipment, 25-W maximum output power (DMC). Figure is available in color online only.

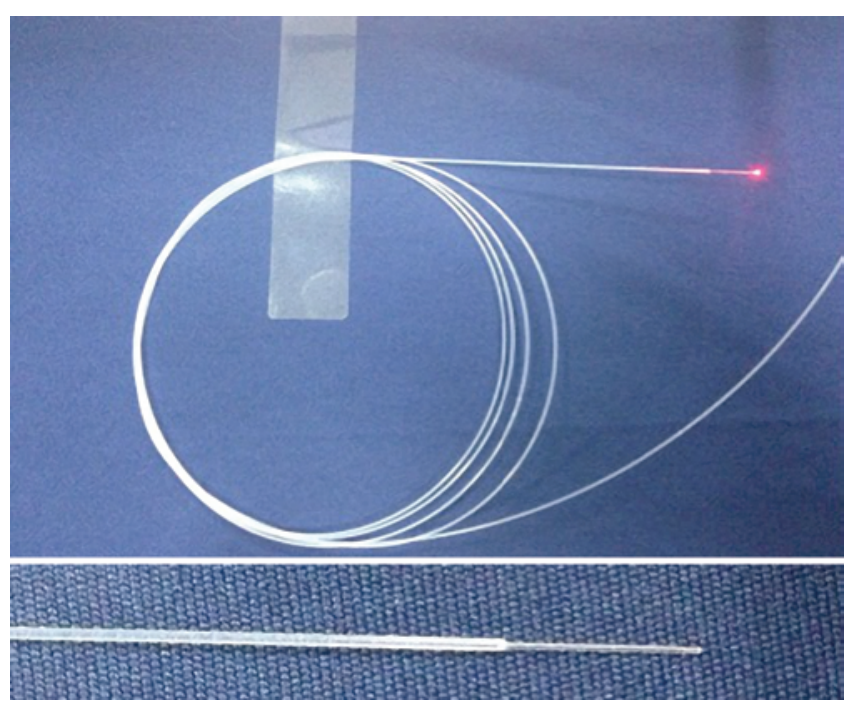

FIG. 2. Biocompatible silica optical fiber with $400-\mu \mathrm{m}$ core used for endoscopic delivery of the 980 -nm diode laser. Figure is available in color online only.

\section{Results \\ Patient Population}

Nine patients (5 males and 4 females), 14-71 years of age, with obstructive hydrocephalus, were treated with diode laser at Hospital das Clínicas, University of São Paulo, Brazil, between January 2012 and March 2013. Table 1 shows the patients' age, sex, symptoms and CT and/or MRI findings at admission, operative procedures, postoperative morbidity, follow-up period, current clinical status, and CT and/or MRI postoperative images.

Headache was the main complaint in our series (5 patients), whereas 2 patients presented with gait disturbance and 3 with papilledema, which were the most common findings on physical examination. One patient was asymptomatic with normal neurological examination. Three patients had undergone previous surgeries: 2 ventriculoperitoneal shunts and 1 craniotomy for suprasellar cyst resection. The most frequent finding on CT and/or MRI, in addition to hydrocephalus, was aqueductal stenosis in 3 patients.

\section{Technical Details}

Endoscopic laser surgeries lasted an average of 60 minutes (range 30-120 minutes). In all 9 cases, the photothermal properties of 980 -nm diode laser were used to promote tissue desiccation, shrinkage, and hemostasis. In endoscopic third ventriculostomy (ETV), diode laser made an initial opening in the third ventricular floor (premammillary membrane), which was then enlarged by Fogarty catheter. In Case 1 (neurocysticercosis), traditional endoscopic-assisted removal of cysticercal cysts was followed by laser application to synechiae and membranes, promoting reestablishment of ventricular anatomy and hydrodynamic patterns, while also treating remaining cysts with thermal action (Fig. 3).

In cases of cystic fenestrations, pineal tumor biopsy, and third ventricular tumor resection (Case 9), the same 
TABLE 1. Age, sex, clinical status, and CT/MRI findings (besides hydrocephalus) at admission and during follow-up in 9 patients with ventricular diseases

\begin{tabular}{|c|c|c|c|c|c|c|c|c|}
\hline $\begin{array}{l}\text { Case } \\
\text { No. }\end{array}$ & $\begin{array}{l}\text { Age } \\
\text { (yrs), } \\
\text { Sex }\end{array}$ & $\begin{array}{l}\text { Symptoms/Signs } \\
\text { at Admission }\end{array}$ & $\begin{array}{l}\text { CT and/or MRI } \\
\text { Findings at } \\
\text { Admission }\end{array}$ & $\begin{array}{l}\text { Surgical } \\
\text { Procedure }\end{array}$ & Postop Morbidity & $\begin{array}{l}\text { Follow- } \\
\text { Up (mos) }\end{array}$ & $\begin{array}{l}\text { Current Clinical } \\
\text { Status }\end{array}$ & $\begin{array}{l}\text { CT and/or } \\
\text { MRI Control }\end{array}$ \\
\hline 1 & $28, \mathrm{M}$ & $\begin{array}{l}\text { Headache, } \\
\text { seizures, } \\
\text { papilledema }\end{array}$ & $\begin{array}{l}\text { Cysticercosis } \\
\text { + ventricular } \\
\text { synechiae }\end{array}$ & $\begin{array}{l}\text { Synechiae } \\
\text { fenestration } \\
+ \text { removal of } \\
\text { Cysticercus }\end{array}$ & None & 13 & $\begin{array}{l}\text { Asymptomatic, } \\
\text { shunt depen- } \\
\text { dence }\end{array}$ & $\begin{array}{l}\text { No lesion, no } \\
\text { hydrocephalus }\end{array}$ \\
\hline 2 & $61, \mathrm{M}$ & Gait disturbance & $\begin{array}{r}\text { Aqueductal } \\
\text { stenosis }\end{array}$ & ETV & $\begin{array}{l}\text { EVD + acute SDH, } \\
\text { death } 24 \text { hrs later }\end{array}$ & * & * & * \\
\hline 3 & $71, \mathrm{~F}$ & Gait disturbance & $\begin{array}{l}\text { Aqueductal } \\
\text { stenosis }\end{array}$ & ETV & None & 13 & Asymptomatic & $\begin{array}{l}\text { No hydrocepha- } \\
\text { lus }\end{array}$ \\
\hline 4 & $27, \mathrm{M}$ & $\begin{array}{l}\text { Asymptomatic, } \\
\text { shunt depen- } \\
\text { dence }\end{array}$ & Pineal tumor & $\begin{array}{l}\text { Pineal tumor } \\
\text { biopsy }\end{array}$ & None & 22 & $\begin{array}{l}\text { Asymptomatic (pa- } \\
\text { tient underwent } \\
\text { tumor resection } \\
\text { during follow-up) }\end{array}$ & $\begin{array}{l}\text { No lesion, no } \\
\text { hydrocephalus }\end{array}$ \\
\hline 5 & $19, \mathrm{~F}$ & $\begin{array}{c}\text { Cognitive impair- } \\
\text { ment, right VI } \\
\text { nerve palsy }\end{array}$ & $\begin{array}{c}\text { Aqueductal } \\
\text { stenosis }\end{array}$ & ETV & $\begin{array}{l}\text { Meningitis and } \\
\text { shunt depen- } \\
\text { dence }\end{array}$ & 19 & $\begin{array}{c}\text { No neurological } \\
\text { deterioration }\end{array}$ & $\begin{array}{l}\text { Shunt depen- } \\
\text { dence + hydro- } \\
\text { cephalus }\end{array}$ \\
\hline 6 & $19, \mathrm{M}$ & $\begin{array}{l}\text { Headache, eye- } \\
\text { sight blurring, } \\
\text { papilledema }\end{array}$ & $\begin{array}{r}\text { Third ventricle } \\
\text { colloid cyst }\end{array}$ & Cyst wall opening & None & 16 & Asymptomatic & $\begin{array}{l}\text { No lesion, no } \\
\text { hydrocephalus }\end{array}$ \\
\hline 7 & $20, F$ & $\begin{array}{r}\text { Headache, } \\
\text { seizures }\end{array}$ & $\begin{array}{l}\text { Posterior fossa } \\
\text { arachnoid } \\
\text { cyst }\end{array}$ & $\begin{array}{l}\text { Cyst wall fenes- } \\
\text { tration }\end{array}$ & None & 9 & Asymptomatic & $\begin{array}{l}\text { Posterior fossa } \\
\text { cyst w/ no } \\
\text { mass effect }\end{array}$ \\
\hline 8 & $26, F$ & Headache & $\begin{array}{l}\text { Suprasellar } \\
\text { cyst }\end{array}$ & $\begin{array}{l}\text { Cyst wall fenes- } \\
\text { tration \& ETV }\end{array}$ & None & $\dagger$ & $\dagger$ & $\dagger$ \\
\hline 9 & $14, \mathrm{M}$ & $\begin{array}{l}\text { Headache, papill- } \\
\text { edema }\end{array}$ & $\begin{array}{l}\text { Third ventricu- } \\
\text { lar tumor }\end{array}$ & $\begin{array}{c}\text { Tumor partial } \\
\text { resection }\end{array}$ & EVD + meningitis & 8 & $\ddagger$ & $\ddagger$ \\
\hline
\end{tabular}

EVD = external ventricular drain; SDH = subdural hematoma.

* Patient died 1 day after surgery (due to cause unrelated to the laser procedure).

$\dagger$ Patient lost to follow-up.

$\ddagger$ Patient suffered sudden death 8 months after surgery.

vaporization properties were applied as an option to perform endoscope-assisted desiccation, resection, and hemostasis.

All patients underwent a postoperative $\mathrm{CT}$ and/or MRI within 24 hours (Fig. 4). Results were abnormal in only 2 examinations: one revealed an acute subdural hematoma in a patient who underwent a third ventriculostomy and external ventricular drain posteriorly, and the other showed a small tumor fragment inside the lateral ventricle following a third ventricle tumor resection. These cases had clinical complications, as described below.

\section{Complications}

Three patients had postoperative complications before hospital discharge. A 61-year-old man underwent an ETV. Due to the proximity of the basilar artery to the third ventricle floor, the laser was only used to make a minimal
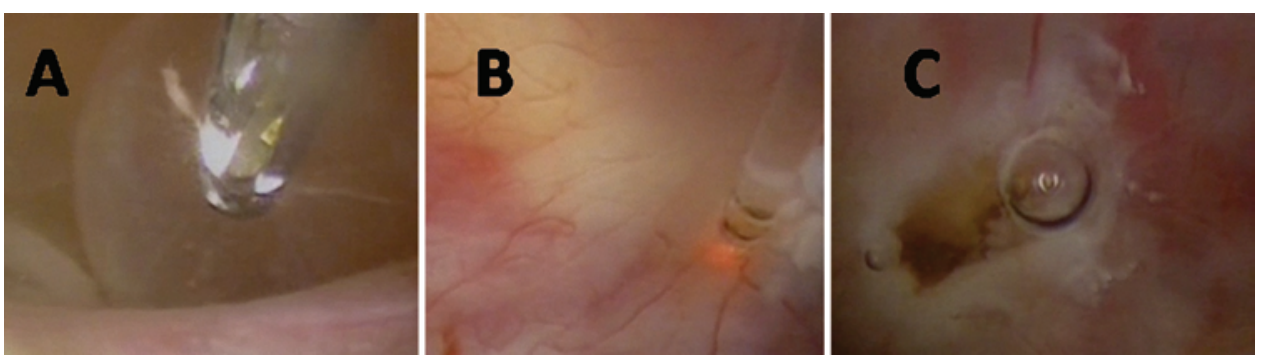

FIG. 3. Treatment of neurocysticercosis with 980-nm diode laser. A: Endoscopic cysticercal cyst removal. B: Laser thermal effect on ventricular synechiae. C: Final synechiae fenestration by laser. 

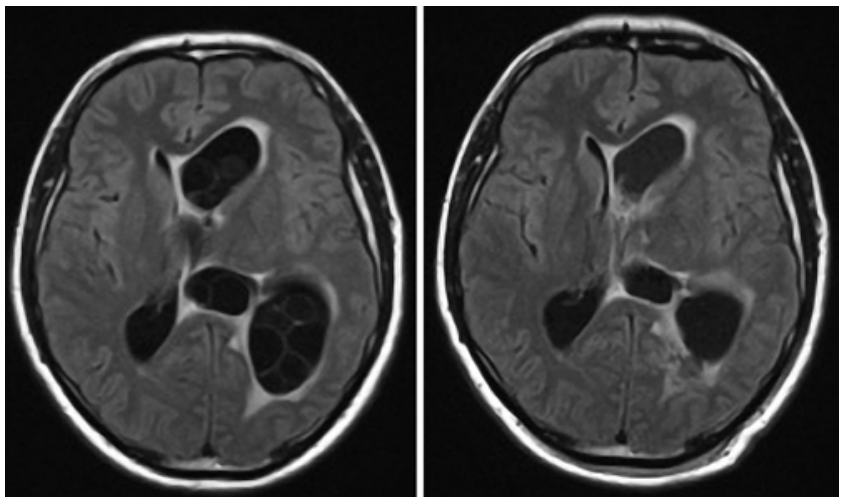

FIG. 4. Case 1 (28-year-old man). Left: Preoperative FLAIR MRI showing ventricular synechiae due to cysticercosis and enlarged left lateral ventricle. Right: First postoperative day: Brain MRI demonstrating smaller left lateral ventricle and fewer cysts.

opening in the premammillary membrane, with no visible hemorrhage. Next, a Fogarty catheter was used to enlarge the perforation, which was when bleeding started. This complication required an external ventricular drain, which led to iatrogenic overdrainage. This patient then presented with an acute subdural hematoma and uncal herniation, which was evacuated by craniotomy. He died 1 day later.

A 14-year-old boy was admitted with an external ventricular drain, and he had a third ventricle tumor that needed a ventriculoperitoneal shunt after partial tumor resection with diode laser. He later contracted meningitis, but was treated and discharged from the hospital without a shunt 4 months after the laser surgery.

A 19-year-old woman with previous cognitive impairment and aqueductal stenosis developed postoperative CSF fistula and meningitis, which required an external ventricular drain and intravenous antibiotics. She needed a ventriculoperitoneal shunt afterward and developed a chronic subdural hematoma due to overdrainage. She underwent surgery and was discharged without a shunt and no additional neurological deficits 4 months after the laser procedure.
The remaining 6 patients had symptom improvement after endoscopic surgery and were discharged from the hospital 24-48 hours after surgery.

\section{Follow-Up}

Eight patients were discharged from the hospital and 1 was lost to follow-up. The remaining 7 were followed up for an average of 14 months (range, 8-22 months). They attended the clinical consultations and underwent $\mathrm{CT}$ and/ or MRI scans (Fig. 5). One patient, who underwent Cysticercus removal and synechiae fenestration, had meningitis 1 month after the procedure and became shunt dependent. He remained asymptomatic afterward. Another patient died at home 8 months after the surgery and the cause of death was not identified. The other 6 patients showed good resolution and were asymptomatic at the last followup consultation.

\section{Discussion}

Rosomoff and Carroll pioneered the use of laser for the treatment of neurosurgical conditions in the 1960s, showing its applicability in glioma resection. ${ }^{13}$ Since then, many laser systems have been applied in neurosurgery procedures, such as $\mathrm{CO}_{2}$, argon, Nd:YAG, and diode lasers, each with remarkably different effects on tissues. Likewise, the use of laser has been extended to almost all fields in neurosurgery, such as functional neurosurgery, peripheral nerves, pediatrics, neuro-oncology, and endoscopic neurosurgery.

The laser-tissue interaction regarding all types of most often used surgical lasers in brain tissues is the photothermal interaction. Briefly, the photothermal interaction relies on the heat release that is followed by local absorption of the laser photons by neurological tissue. Absorption events induce vibrational molecular movements and inelastic collisions, which in turn release energy in the form of heat (thermal energy) to the adjacent region. The corresponding local temperature enhancement acts by promoting coagulation and photothermal ablative effects. Together these actions make the procedure safer
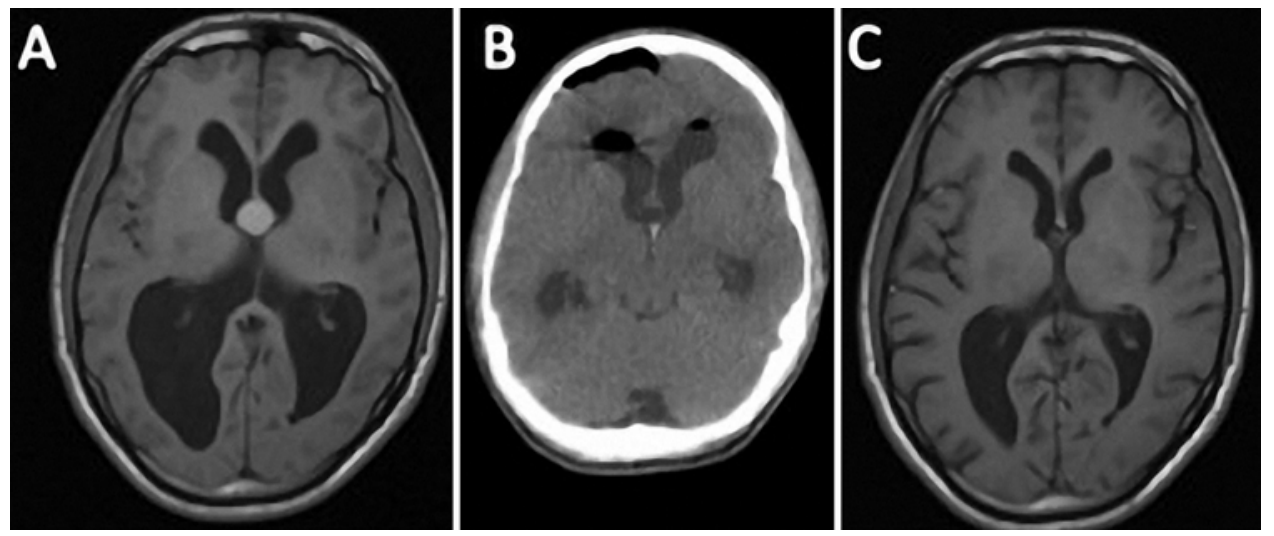

FIG. 5. Case 6 follow-up. A: Preoperative T1-weighted MRI obtained in this 19-year-old man demonstrating hydrocephalus and a colloid cyst in the third ventricle. B: First postoperative day: CT scan showing complete removal of the colloid cyst, pneumocephalus, and ventricular size reduction. C: Head MRI 17 months after the 980-nm diode laser procedure showing sustained ventricular volume reduction. 
TABLE 2. Comparative absorption coefficient of water, $\mu_{A}\left(H_{2} \mathrm{O}\right)$, as function of laser wavelength and advantages/disadvantages of laser systems

\begin{tabular}{|c|c|c|c|}
\hline $\begin{array}{l}\text { Main Laser Technology } \\
\text { Used in Neurosurgeryl } \\
\text { Wavelength }\end{array}$ & $\mu_{A}\left(\mathrm{H}_{2} \mathrm{O}\right)\left(\mathrm{cm}^{-1}\right)^{*}$ & Advantages & Disadvantages \\
\hline $\begin{array}{l}\mathrm{CO}_{2} \text { gas laser } / 10,600 \\
\mathrm{~nm} \dagger(10.6 \mu \mathrm{m})\end{array}$ & 792.00 & $\begin{array}{l}\text { Very low penetration depths (corresponding to very } \\
\text { high surgical precision for ablation). }\end{array}$ & $\begin{array}{l}\text { a) Poor coagulation effect; } \\
\text { b) conventionally articulated arm delivery (optical } \\
\text { fiber delivery is required for neuroendoscopy); } \\
\text { c) microscope assembly is required; } \\
\text { d) requires frequent maintenance regarding gas } \\
\text { laser-medium substitution and articulated arm/ } \\
\text { aiming beam alignments; } \\
\text { e) high acquisition and maintenance costs. }\end{array}$ \\
\hline $\begin{array}{l}\text { Nd:YAG solid } \\
\text { state/1064 } \mathrm{nm}(1.06 \\
\mu \mathrm{m})\end{array}$ & 0.12 & $\begin{array}{l}\text { a) Coagulation and ablation simultaneously; } \\
\text { b) noncontact and contact modes optical energy } \\
\text { delivery. }\end{array}$ & $\begin{array}{l}\text { a) Large penetration depths in poorly pigmented } \\
\text { tissues (very broad coagulation zones); } \\
\text { b) high-priced equipment; } \\
\text { c) needs constant changing of the pumping mecha- } \\
\text { nism and laser medium (bulk Nd:YAG crystal). }\end{array}$ \\
\hline $\begin{array}{l}\text { Semiconductor diode } \\
\text { (AlGaAs)/805-810 } \\
\text { nm }\end{array}$ & 0.02 & $\begin{array}{l}\text { a) Coagulation and ablation effects; } \\
\text { b) noncontact and contact modes optical energy } \\
\text { delivery; } \\
\text { c) convenient cost-effectiveness regarding equip- } \\
\text { ment and fibers; } \\
\text { d) long laser-emitter lifetime. }\end{array}$ & $\begin{array}{l}\text { Very large penetration depths in poorly pigmented } \\
\text { tissues (very broad coagulation zones). }\end{array}$ \\
\hline $\begin{array}{l}\text { Semiconductor diode } \\
\quad(\operatorname{InGaAs}) / 980 \mathrm{~nm}\end{array}$ & 0.45 & $\begin{array}{l}\text { a) Coagulation and ablation effects; } \\
\text { b) noncontact and contact modes optical energy } \\
\text { delivery; } \\
\text { c) lower penetration depths in poorly pigmented tis- } \\
\text { sues than previous diode lasers ( } 805-810 \mathrm{~nm}) \text {; } \\
\text { d) convenient cost-effectiveness regarding equip- } \\
\text { ment and fibers; } \\
\text { e) long laser-emitter lifetime. }\end{array}$ & No appreciable disadvantages. \\
\hline
\end{tabular}

${ }^{*}$ The $\mu_{\mathrm{A}}\left(\mathrm{H}_{2} \mathrm{O}\right)$ is inversely proportional to penetration depths of laser light into tissue.

$\dagger$ A nontoxic optical fiber for $\mathrm{CO}_{2}$ laser delivery has recently become available.

when compared with the single mechanical effect of nonlaser devices, such as Fogarty catheter ${ }^{20}$ Among the main current applications of lasers in neurosurgery are minimally invasive procedures based on laser-assisted endoscopic interventions. Devaux et al. described 40 cases of laser-assisted (Nd:YAG and 805-nm diode laser) ETV and concluded that the technique is safe and efficient for the treatment of obstructive hydrocephalus. ${ }^{4}$ Four years later, van Beijnum et al. reported results from a series of 202 patients treated with laser-assisted ETV, confirming its effectiveness, especially in patients 1 year of age and older, as well as in patients with aqueductal stenosis and tumors. These authors reported technically successful procedures in $97 \%$ of patients, with a 2-year follow-up success rate of $68 \%$ and complication rate of $10.3 \%$, with only $1(0.5 \%)$ major complication. ${ }^{18}$ These results are similar to the overall success rates (60\%-84\% at 2 years) of most of the studies published in this field. ${ }^{3,4,18}$

In this series, we proposed, for the first time, the clinical use of 980-nm-wavelength diode laser in endoscopic surgeries based on its physical advantages in comparison with 1064-nm Nd:YAG and 805- to 810-nm diode lasers. In laser-assisted neurosurgery involving soft tissues, their water content appears as the main chromophore due to its large amount $(77 \%-78 \%)$ in a composition that includes water, lipids, proteins, carbohydrates, organic substances, and inorganic salts. Thus, the absorption coefficient of water, $\mu_{A}\left(\mathrm{H}_{2} \mathrm{O}\right)$, is one of the main parameters to be considered regarding the election of a surgical laser system. The higher the absorption coefficient, the lower the energy necessary for the procedure, as well as the lower the optical penetration depth in tissue, with milder thermal side effects and less severe coagulation necrosis zones (an important safety aspect). At the 980-nm wavelength, $\mu_{\mathrm{A}}\left(\mathrm{H}_{2} \mathrm{O}\right)=0.45 \mathrm{~cm}^{-1}$, and hence this laser is favorably compared with the 1064-nm Nd:YAG, for which $\mu_{A}\left(\mathrm{H}_{2} \mathrm{O}\right)$ $=0.12 \mathrm{~cm}^{-1}$, and with the 805- to 810-nm diode laser, for which $\mu_{\mathrm{A}}\left(\mathrm{H}_{2} \mathrm{O}\right)=0.02 \mathrm{~cm}^{-1}$. Although the $\mathrm{CO}_{2}$ absorption coefficient of water is higher $-\mu_{\mathrm{A}}\left(\mathrm{H}_{2} \mathrm{O}\right)=792.00 \mathrm{~cm}^{-1}-$ it has several technical and cost disadvantages, which prevent it from being broadly used (Table 2). ${ }^{14,16}$ In addition, the $980-\mathrm{nm}$ laser is well absorbed by both water and hemoglobin, which makes it a versatile tool for a broad range of applications. Another advantage is that the 980$\mathrm{nm}$ light is more absorbed than the 1064-nm light by both oxy- and deoxyhemoglobin.,19 
These theoretical advantages of the 980-nm diode laser have previously been studied in vivo. Gülsoy et al. studied histological specimens of brain from Wistar rats, which had been irradiated with $980-\mathrm{nm}$ diode laser in a stereotaxic neurosurgical procedure. They concluded that, with proper selection of power level and exposure duration, target tissues could be evaporated and/or coagulated. Therefore, they found that the 980 -nm diode laser is a promising tool for neurosurgical applications. ${ }^{5}$

Bozkulak et al. assessed the $980-\mathrm{nm}$ diode laser in an in vivo experimental study on the depth of tissue thermal changes and the recovery process of bilaterally induced cerebral lesions by the 980-nm diode laser and a monopolar probe of an electrocoagulator. Both equipment parameters were adjusted to produce the same lesion sizes. The animals were killed after 0,2 , and 7 days for evaluation of the necrotic tissue areas. These authors concluded that the 980-nm diode laser had excellent ablation capacity with minimal thermal side effects on nearby tissues. ${ }^{1}$

Although application of the 980-nm diode laser in the neurosurgical field has been demonstrated in intracranial neoplasms and lumbar discogenic pain, ${ }^{2,8,9}$ we demonstrate its use with endoscopy for the first time. Our intention is to reduce the invasiveness of intracranial procedures while preventing brain tissue trauma, to decrease the risk of neurological and mental deficits. The intracranial endoscopy proved to be a minimally invasive technique that provides rapid access to the target via a small bur hole without the need for brain retraction. It also allows coagulation and dissection with the use of laser through direct visualization of all treated structures.

We described 980-nm diode laser application in the endoscopic management of intraventricular neurosurgical pathologies in 9 cases, in which it was used mainly as a therapeutic tool. Its potential for cutting and coagulating simultaneously was used to perform a pineal tumor biopsy, which also showed its importance in collecting tissue to provide a diagnosis.

There were 3 perioperative complications in this study. One patient had bleeding after Fogarty catheter use in a previous opening made by diode laser. Because significant bleeding caused by Fogarty catheter is very unusual and laser use could lead to some superficial vessel injury, we cannot rule out the possibility that the laser may have been partly responsible for the bleed. The patient needed an external ventricular drain, which overdrained, and he developed an acute subdural hematoma that was evacuated. Nonetheless, the patient died 1 day after the procedure. The other 2 complications were meningitis, 1 of these cases secondary to a shunting device and the other due to CSF fistula. The patients were treated with intravenous antibiotics and discharged free of symptoms.

One patient did not come to follow-up consultations. We followed the remaining 7 patients for an average of 14 months. One patient died 8 months after surgery and the cause of death was not identified. He did not have any neurological symptoms before he died. The other 6 patients showed good resolution and were asymptomatic during follow-up.

Our group previously studied the role of Nd:YAG laser in the removal of third ventricular colloid cysts using a stereotactic neuroendoscopy-guided procedure in 7 cases. Two patients had postoperative complications: diabetes insipidus and chemical aseptic meningitis. They were treated and discharged from the hospital without sequelae. ${ }^{10}$ It is difficult to compare these results with our present study because we used a 980-nm diode laser to treat ventricular pathologies other than colloid cysts. However, we did not find any difference relative to their intraoperative use and had good results using both devices.

Our results are encouraging, but are still in development. They propose another option when using neuroendoscopy with high precision and quality. However, we need to be cautious until studies that have larger samples and compare $980-\mathrm{nm}$ diode laser with other techniques are developed to confirm the theoretical advantages of this device. Furthermore, newer diode laser systems based on longer wavelengths (1470 $\mathrm{nm}$ and 1910-1940 nm), corresponding to more intense peaks of the water absorption spectrum, should also be experimentally evaluated. These longer-wavelength diode lasers have potential as precise tools concerning minimally invasive neurosurgical applications and a favorable cost-benefit analysis.

\section{Conclusions}

The high precision and hemostatic effects of the 980$\mathrm{nm}$ diode laser are highly convenient. In addition to its role in collecting tissue to provide a diagnosis, we consider the 980-nm diode laser to be an important therapeutic tool for endoscopic neurological surgeries. In this report we showed its application in different diseases such as aqueductal stenosis, neurocysticercosis, arachnoid cysts, and intraventricular tumors.

\section{References}

1. Bozkulak O, Tabakoglu HO, Aksoy A, Kurtkaya O, Sav A, Canbeyli R, et al: The 980-nm diode laser for brain surgery: histopathology and recovery period. Lasers Med Sci 19:4147, 2004

2. Brouwer PA, Peul WC, Brand R, Arts MP, Koes BW, van den Berg AA, et al: Effectiveness of percutaneous laser disc decompression versus conventional open discectomy in the treatment of lumbar disc herniation; design of a prospective randomized controlled trial. BMC Musculoskelet Disord 10:49, 2009

3. Buxton N, Ho KJ, Macarthur D, Vloeberghs M, Punt J, Robertson I: Neuroendoscopic third ventriculostomy for hydrocephalus in adults: report of a single unit's experience with 63 cases. Surg Neurol 55:74-78, 2001

4. Devaux BC, Joly LM, Page P, Nataf F, Turak B, Beuvon F, et al: Laser-assisted endoscopic third ventriculostomy for obstructive hydrocephalus: technique and results in a series of 40 consecutive cases. Lasers Surg Med 34:368-378, 2004

5. Gülsoy M, Çelikel T, Kurtkaya O, Sav A, Kurt A, Canbeyli R, et al: Application of the 980-nm diode laser in stereotaxic surgery. IEEE J Sel Top Quantum Electron 5:1090-1094, 1999

6. Hellwig D, Bauer BL, Schulte M, Gatscher S, Riegel T, Bertalanffy H: Neuroendoscopic treatment for colloid cysts of the third ventricle: the experience of a decade. Neurosurgery 52:525-533, 2003

7. Husain M, Jha DK, Rastogi M, Husain N, Gupta RK: Neuroendoscopic management of intraventricular neurocysticercosis (NCC). Acta Neurochir (Wien) 149:341-346, 2007 
8. Jethwa PR, Barrese JC, Gowda A, Shetty A, Danish SF: Magnetic resonance thermometry-guided laser-induced thermal therapy for intracranial neoplasms: initial experience. Neurosurgery 71 (1 Suppl Operative): 133-144, 144-145, 2012

9. Menchetti PP, Canero G, Bini W: Percutaneous laser discectomy: experience and long term follow-up. Acta Neurochir Suppl 108:117-121, 2011

10. Pinto FC, Chavantes MC, Fonoff ET, Teixeira MJ: Treatment of colloid cysts of the third ventricle through neuroendoscopic Nd: YAG laser stereotaxis. Arq Neuropsiquiatr 67:1082-1087, 2009

11. Pinto FC, Chavantes MC, Pinto NC, Alho EJ, Yoshimura EM, Matushita H, et al: Novel treatment immediately after myelomeningocele repair applying low-level laser therapy in newborns: a pilot study. Pediatr Neurosurg 46:249-254, 2010

12. Proaño JV, Torres-Corzo J, Rodríguez-Della Vecchia R, Guizar-Sahagun G, Rangel-Castilla L: Intraventricular and subarachnoid basal cisterns neurocysticercosis: a comparative study between traditional treatment versus neuroendoscopic surgery. Childs Nerv Syst 25:1467-1475, 2009

13. Rosomoff HL, Carroll F: Reaction of neoplasm and brain to laser. Arch Neurol 14:143-148, 1966

14. Ryan RW, Wolf T, Spetzler RF, Coons SW, Fink Y, Preul MC: Application of a flexible $\mathrm{CO}(2)$ laser fiber for neurosurgery: laser-tissue interactions. J Neurosurg 112:434-443, 2010

15. Schroeder HW, Gaab MR: Endoscopic resection of colloid cysts. Neurosurgery 51:1441-1445, 2002

16. Sroka R, Havel M, Betz C, Kremser T, Leunig A: Clinical feasibility trial on $1940 \mathrm{~nm}$ Tm: fiber laser intervention of hyperplastic inferior nasal turbinates. Photon Lasers Med 1:215-222, 2012
17. Tirakotai W, Schulte DM, Bauer BL, Bertalanffy H, Hellwig D: Neuroendoscopic surgery of intracranial cysts in adults. Childs Nerv Syst 20:842-851, 2004

18. van Beijnum J, Hanlo PW, Fischer K, Majidpour MM, Kortekaas MF, Verdaasdonk RM, et al: Laser-assisted endoscopic third ventriculostomy: long-term results in a series of 202 patients. Neurosurgery 62:437-444, 2008

19. Vandertop WP, Verdaasdonk RM, van Swol CFP: Laserassisted neuroendoscopy using a neodymium-yttrium aluminum garnet or diode contact laser with pretreated fiber tips. J Neurosurg 88:82-92, 1998

20. Vo-Dinh T: Biomedical Photonics Handbook. Boca Raton, FL: CRC Press, 2003

\section{Author Contributions}

Conception and design: Teixeira, Mancini, Almeida-Lopes, Pinto. Acquisition of data: Reis, Teixeira, Pinto. Analysis and interpretation of data: Reis, Teixeira, Almeida-Lopes, Pinto. Drafting the article: Reis, Teixeira, Mancini, Almeida-Lopes, Pinto. Critically revising the article: Reis, Mancini, Almeida-Lopes, de Oliveira, Pinto. Reviewed submitted version of manuscript: Reis, Mancini, Almeida-Lopes, de Oliveira, Pinto. Approved the final version of the manuscript on behalf of all authors: Reis. Administrative/ technical/material support: Pinto. Study supervision: Reis, Mancini, Almeida-Lopes, Pinto.

\section{Correspondence}

Rodolfo Casimiro Reis, Neurosurgery Residency Program, Hospital do Servidor Público Estadual de São Paulo, Rua Dr Diogo de Faria, 1201, Apt 184, Vila Clementino, 04037004 São Paulo, SP, Brazil.email: rodolfocr84@yahoo.com.br. 